\title{
PENGARUH PENGGUNAAN LARUTAN ALKALI DALAM KEKUATAN BENTUR DAN UJI DEGRADASI PADA KOMPOSIT TERMOPLASTIK BERPENGISI SERBUK SERABUT KELAPA
}

\author{
Harry Abrido S, Johannes Leonard S, Maulida \\ Departemen Teknik Kimia, Fakultas Teknik, Universitas Sumatera Utara, \\ Jl. Almamater Kampus USU Medan 20155, Indonesia \\ email: harryabrido@students.usu.ac.id
}

\begin{abstract}
Abstrak
Komposit merupakan gabungan dua bahan yang berlainan untuk memperoleh bahan dengan sifat-sifat fisik dan mekanik yang lebih baik dibandingkan sifat setiap komponen pembentuknya. Salah satu jenis komposit yang banyak dihasilkan adalah komposit berpengisi serbuk alami. Penelitian ini menggunakan matriks polipropilena bekas yang berasal dari aqua cup bekas dan pengisi serbuk serabut kelapa yang telah diolah dengan Natrium Hidroksida (NaOH). Rasio perbandingan antara matriks dan pengisi adalah 85:15. Rasio ini merupakan nilai optimum yang diperoleh berdasarkan kekuatan uji tarik komposit dengan beberapa rasio yaitu 100:0 , 95:5, 90:10 dan 85:15. Tujuan penelitian ini adalah untuk mengetahui pengaruh penggunaan larutan alkali terhadap sifat komposit yang dihasilkan berupa kekuatan hantam, serta pengaruh uji degradasi terhadap bahan komposit polipropilen bekas berpengisi serabut kelapa. Variasi uji degradasi komposit adalah 10, 20 dan 30 hari dan perendaman serbuk selama 1 dan 2 hari. Metode yang digunakan dalam pembuatan komposit ini adalah metode ekstrusi. Matriks berupa polipropilena bekas dicampur dengan serbuk serabut kelapa yang telah direndam dengan $\mathrm{NaOH}$, kemudian dicampur di dalam sebuah wadah, kemudian dimasukkan ke dalam ekstruder dengan suhu operasi $175^{\circ} \mathrm{C}$, dicetak dengan menggunakan hot press pada suhu $175^{\circ} \mathrm{C}$, dan dipotongpotong sesuai pengujian. Hasil penelitian menunjukkan bahwa terjadi pengolahan optimum dengan $\mathrm{NaOH}$ selama 2 hari. Hasil uji degradasi menunjukkan perendaman selama 2 hari memiliki nilai kekuatan bentur yang lebih tinggi dibandingkan 1 hari yaitu sebesar 0,086 J/mm pada 10 hari, 0,048 J/mm pada 20 hari dan 0,052 J/mm pada 30 hari.
\end{abstract}

Kata kunci: Komposit, polipropilena bekas, serabut kelapa, $\mathrm{NaOH}$, uji degradasi

\begin{abstract}
Composite is a combination of two different materials to obtain a material with physical properties and mechanical properties are better than any of its constituent parts. One of the many types of produced composite is composite with powdered natural fiber. This study uses the former polypropylene matrix derived from aqua cup and powdered coconut fiber as filler treated with Sodium Hydroxide (NaOH). The ratio of the matrix and the filler is 85:15. This ratio is the optimum value obtained by the composite tensile strength with some ratios are 100:0, 95:5, 90:10 and 85:15. The purpose of this study was to determine the effect of the use of an alkaline solution of the resulting composite properties such as impact strength, as well as the effect of degradation test on composite material former polypropylene with powdered coconut fiber as filler. Variation of composite degradation test were 10, 20 and 30 days, and immersion powder for 1 and 2 days. The method used in the manufacture of composites is the method of extrusion. The matrix form of the former polypropylene mixed with coconut fiber powder that has been soaked with $\mathrm{NaOH}$, then mixed in a container, then put into the extruder operating temperature $1750 \mathrm{C}$, printed using a hot press at a temperature of $1750 \mathrm{C}$, and cut into pieces appropriate testing. The results showed that the optimum processing occurs with $\mathrm{NaOH}$ for 2 days. The test results showed degradation soaking for 2 days has impact strength values higher than 1 day is equal to $0.086 \mathrm{~J} / \mathrm{mm}$ at 10 days, $0.048 \mathrm{~J} / \mathrm{mm}$ at 20 days and $0.052 \mathrm{~J} / \mathrm{mm}$ at 30 days.
\end{abstract}

Keywords : Composite, former polypropylene, coconut fiber, $\mathrm{NaOH}$, degradation test

\section{Pendahuluan}

Pada dekade terakhir ini perkembangan teknologi semakin pesat, terutama di bidang bahan teknik. Salah satu kemajuan di bidang bahan teknik adalah pemanfaatan bahan komposit untuk berbagai keperluan seperti alat transportasi baik transportasi darat, laut, dan udara.
Komposit dengan berpenguat serat alam menjadi salah satu pilihan yang tepat. Serat alam lebih dipilih dibanding serat buatan, karena serat alam memiliki beberapa kelebihan diantaranya adalah kaku, murah, ringan, tidak beracun, tersedia dalam jumlah yang banyak, dan ramah lingkungan [1][3]. 
Adapun salah satu jenis tanaman yang menghasilkan serat alam adalah kelapa dengan nama latin Cocos nucifera. Selama ini serabut kelapa hanya digunakan sebagai bahan dasar pembuatan keset, sikat, dan lain-lain [14]. Hal yang menjadi pertimbangan penggunaan serat ini adalah penggunaan serabut kelapa yang masih minim dan serat ini mudah diperoleh serta serat ini juga memiliki sifat yang kuat. Penelitian mengenai penggunaan serabut kelapa sebagai pengisi komposit termoplastik telah banyak dilakukan. Salah satu penelitian dilakukan oleh University of Delft, dimana komposit polipropilen berpengisi serabut kelapa menghasilkan flexural strength 29-49 MPa dan flexural stiffness 2,91-2,99 GPa [2].

Jenis termoplastik yang digunakan dalam penelitian ini adalah polipropilen (PP) bekas dari aqua cup. Polipropilen (PP) adalah sebuah polimer termoplastik yang dibuat oleh industri kimia dan digunakan dalam berbagai aplikasi.

Penggunaan larutan alkali sebagai langkah perlakuan terhadap serat telah dilakukan. Salah satunya dilakukan oleh Kuncoro dimana poliester berpengisi serat rami diperlakukan dengan larutan alkali yaitu larutan natrium hidrosida $(\mathrm{NaOH})$. Komposit yang dihasilkan memiliki tegangan tarik 190 MPa dan modulus elastisitas 45,795 GPa [1]. Penelitian yang dilakukan Rohatgi menyatakan perendaman serabut kelapa dalam larutan 5\% NaOH selama 72 jam memberikan kekuatan tarik terbaik [8]. Berbeda dengan Mohanty menyatakan perendaman dalam larutan $2 \% \mathrm{NaOH}$ selama 1 jam memberikan kekuatan tarik optimum [5].

Dikarenakan sifat dan karakteristiknya yang unik, kayu merupakan bahan yang paling banyak digunakan untuk keperluan konstruksi. Kebutuhan manusia akan kayu sebagai bahan bangunan baik untuk keperluan konstruksi, dekorasi, maupun furniture terus meningkat seiring dengan meningkatnya jumlah penduduk. Kebutuhan kayu untuk industri perkayuan di Indonesia diperkirakan sebesar 70 juta $\mathrm{m}^{3}$ per tahun dengan kenaikan rata-rata sebesar 14,2 \% per tahun sedangkan produksi kayu bulat diperkirakan hanya sebesar 25 juta $\mathrm{m}^{3}$ per tahun, dengan demikian terjadi defisit sebesar 45 juta $\mathrm{m}^{3}$ [6]. Kondisi ini menuntut penggunaan kayu secara efisien dan bijaksana, antara lain melalui konsep the whole tree utilization, dan pengembangan produk-produk inovatif sebagai bahan bangunan pengganti kayu. Di lain pihak, seiring dengan perkembangan teknologi, kebutuhan akan plastik terus meningkat. Sebagai konsekuensinya, peningkatan limbah plastikpun tidak terelakkan. Limbah plastik merupakan bahan yang tidak dapat terdekomposisi oleh mikroorganisme pengurai (nonbiodegradable), sehingga penumpukkannya di alam dikhawatirkan akan menimbulkan masalah lingkungan. Oleh karena itu penelitian ini juga bermanfaat untuk mendaur ulang limbah plastik yaitu polipropilen bekas dari aqua cup untuk mengurangi penumpukan limbah plastik di alam.

Pengujian degradasi komposit termoplastik dalam penelitian ini juga dilakukan didasarkan atas penelitian yang telah dilakukan untuk meneliti degradasi komposit [7]. Dalam penelitian ini, degradasi komposit dilakukan berdasarkan kelembapan, pergantian kelembapan, suhu, dan pergantian suhu sesuai dengan cuaca lingkungan.

\section{Teori}

Komposit adalah bahan padat yang dihasilkan melalui kombinasi dari dua atau lebih bahan yang berlainan dengan sifat-sifat yang lebih baik dan tidak dapat diperoleh dari setiap komponen penyusunnya. Komposit sudah digunakan oleh manusia sejak awal abad ke-12. Dewasa ini, pemakaian bahan komposit semakin banyak digunakan seperti dalam bidang penerbangan, konstruksi bangunan, automobil, peralatan olahraga, perabot dan sebagainya [12].

Komposit mempunyai banyak kelebihan dan keistimewaan dari segi sifat mekanis, fisik, termal, dan kimianya, yaitu:

a) Sifat kekuatan, kekakuan dan keliatannya yang cukup baik .

b) Kestabilan dimensi dan ketahanan termal yang tinggi.

c) Peningkatan modulus spesifik (modulus / massa jenis ) dan kekuatan spesifik (kekuatan / massa jenis) menyebabkan berat jenis komposit semakin berkurang.

d) Peningkatan ketahanan terhadap bahan kimia.

e) Biaya produksi dapat dikurangi karena bahan dasar yang digunakan berkurang

Namun perlu diketahui bahwa semua sifat diatas tidak dapat diperoleh secara bersamaan. Misalnya, peningkatan sifat kekakuan dan kekuatan umumnya mengurangi sifat keliatan bahan komposit tersebut. Jadi pencapaian kekuatan optimum komposit yang dihasilkan disesuaikan dengan penggunaan komposit tersebut.

Sodium Hydroxide atau Natrium Hidroksida adalah sejenis basa logam kaustik. 
Zat ini digunakan di berbagai macam bidang industri, kebanyakan digunakan sebagai basa dalam proses produksi bubur kayu dan kertas, tekstil, air minum,sabun dan deterjen. Kegunaan $\mathrm{NaOH}$ ini adalah untuk menghilangkan lignin, silika hemiselulosa, dan empulur dari serat agar memiliki impregnasi lebih baik antara serat dan matriks dan meningkatkan kekasaran permukaan serat agar dapat terjadi interaksi yang lebih baik yang menjadi tujuan utama pengolahan secara kimia [8].

Polipropena (PP) merupakan polimer hidrokarbon yang termasuk ke dalam polimer termoplastik yang dapat diolah pada suhu tinggi. Polipropilen berasal dari monomer propilen yang diperoleh dari pemurnian minyak bumi. Struktur molekul propilen dapat dilihat pada gambar berikut.<smiles>C=CC</smiles>

Gambar 1. Struktur Molekul Propilena

Adapun karakteristik dari PP dapat dilihat pada Tabel 1 berikut ini [16].

Tabel 1. Karakteristik Polipropilen

\begin{tabular}{|l|l|l|}
\hline Sifat-sifat & Nilai & Satuan \\
\hline Densitas & 0,9 & $\mathrm{~g} / \mathrm{cm}^{3}$ \\
\hline Tensile Strength & 360 & $\mathrm{~kg} / \mathrm{cm}^{2}$ \\
\hline Pemanjangan/Elongation & 8 & $\%$ \\
\hline $\begin{array}{l}\text { Laju alir pelelehan } \\
\left(230^{\circ} \mathrm{C} / 2,16 \mathrm{~kg}\right)\end{array}$ & 7,5 & $\begin{array}{l}\mathrm{g} / 10 \\
\text { menit }\end{array}$ \\
\hline $\begin{array}{l}\text { Daya serap air setelah } 24 \\
\text { jam }\end{array}$ & 0,02 & $\%$ \\
\hline $\begin{array}{l}\text { Modulus kelenturan } \\
\text { (Flexural modulus })\end{array}$ & 17.000 & $\mathrm{~kg} / \mathrm{cm}^{2}$ \\
\hline Titik leleh & 176 & ${ }^{0} \mathrm{C}$ \\
\hline
\end{tabular}

Serabut kelapa berada diantara tempurung kelapa dan kulit kelapa. Setiap sel serat berbentuk panjang dan berongga dengan dinding tipis yang terbuat dari selulosa. Dinding ini lemah saat masih muda namun semakin lama semakin mengeras dan menguning dimana terbentuk lapisan lignin pada dindingnya. Tiap sel memiliki panjang $1 \mathrm{~mm}(0,04$ in) dan berdiameter $10-20 \mu \mathrm{m}$ (0,0004-0,0008 in). Seratnya memiliki panjang $10-20 \mathrm{~cm}$ (4-12 in). Terdapat 2 jenis dari serabut kelapa. Jenis pertama adalah berwarna coklat yang diperoleh dari kelapa yang sudah tua. Serat ini tipis, dan kuat sehingga digunakan untuk sikat dan keset kaki [15].

Adapun sifat-sifat fisika dan kimia dari serabut kelapa dapat dilihat pada Tabel 2 dan 3 berikut ini [2][4].

Tabel 2. Sifat-sifat Fisika Serabut Kelapa

\begin{tabular}{|l|l|l|}
\hline Sifat-sifat & Nilai & Satuan \\
\hline Densitas & 1,25 & $\mathrm{~g} / \mathrm{cm}^{3}$ \\
\hline Tensile Strength & 220 & $\mathrm{MPa}$ \\
\hline $\begin{array}{l}\text { Elongation } \\
\text { modulus }\end{array}$ & 6 & $\mathrm{GPa}$ \\
\hline $\begin{array}{l}\text { Elongation at } \\
\text { failure }\end{array}$ & $15-25$ & $\%$ \\
\hline
\end{tabular}

Tabel 3. Komposisi Kimia Serabut Kelapa

\begin{tabular}{|l|l|}
\hline Komposisi & Nilai (\%) \\
\hline Selulosa & $32-43$ \\
\hline Hemiselulosa & $0,15-0,25$ \\
\hline Lignin & $40-45$ \\
\hline Pektin & $3-4$ \\
\hline Kelembaban & 8 \\
\hline
\end{tabular}

Komposit memiliki banyak jenis uji, tetapi yang dibahas dalam penelitian ini adalah sebagai berikut:

1. Uji sifat kekuatan patah/bentur (impact strength)

Besaran sifat mekanis yang lain adalah kekuatan bentur, yang didefenisikan sebagai energi yang diperlukan untuk memecahkan spesimen. Spesimen ditempatkan pada suatu "pemegang" dengan salah satu ujungnya vertikal diatas pemegang. Suatu pendulum dengan bobot dan sudut tertentu diayunkan pada spesimen sampai terjadi patahan. Kekuatan bentur dihitung dari energi benda jatuh yang digunakan memecahkan spesimen sampai setengah bagian. Kekuatan patah dapat dinyatakan dalam persamaan sebagai berikut :

Kekuatan patah : $\mathbf{m . g} .\left(h_{0}-h_{f}\right)$

Dimana : Kekuatan patah (Joule) $\mathrm{m}=$ massa pendulum $(\mathrm{Kg})$ $\mathrm{g}=$ percepatan gravitasi $\left(9,8 \mathrm{~m} / \mathrm{s}^{2}\right)$ $\mathrm{h}_{\mathrm{o}}=$ tinggi awal pendulum $(\mathrm{m})$ $\mathrm{h}_{\mathrm{f}}=$ tinggi pendulum setelah spesimen patah

\section{Uji degradasi}

Degradasi dari polimer melalui suatu tahap, dimana pertama polimer diubah menjadi monomer, lalu monomer tersebut menjadi mineral. Kebanyakan polimer terlalu besar untuk melalui membran sel, jadi polimer tersebut terlebih dahulu di depolimerisasi menjadi monomer-monomer sebelum diserap dan dibiodegradasi oleh mikroba. Pemecahan 
awal dari sebuah polimer dapat diperoleh dari cara fisik, kimia dan biologi. Pemecahan secara fisik berupa pemanasan/pendinginan, pembekuan/pencairan,

pembasahan/pengeringan, dapat menghasilkan kerusakan mekanik berupa keretakan. Pertumbuhan dari jamur juga dapat membuat pembengkakkan dan letusan, dikarenakan jamur menembus permukaan padatan polimer. Hal ini memperburuk keadaan permukaan polimer dan membuat permukaan baru yang bereaksi dengan senyawa kimia dan biokimia, yang merupakan kondisi kritis pada degradasi polimer padatan [9].

Polipropilena dapat mengalami degradasi rantai saat terkena radiasi ultraungu dari sinar matahari. Jadi untuk penggunaan propilena di luar ruangan, bahan aditif yang menyerap ultraungu harus digunakan. Jelaga (celak) juga menyediakan perlindungan dari serangan UV. Polimer bisa dioksidasi pada suhu yang tinggi, merupakan permasalahan yang umum dalam operasi pencetakan. Antioksidan normalnya ditambahkan untuk mencegah degradasi atau oksidasi polimer.

Hasil

A. Penentuan Rasio Optimum berdasarkan Kekuatan Tarik

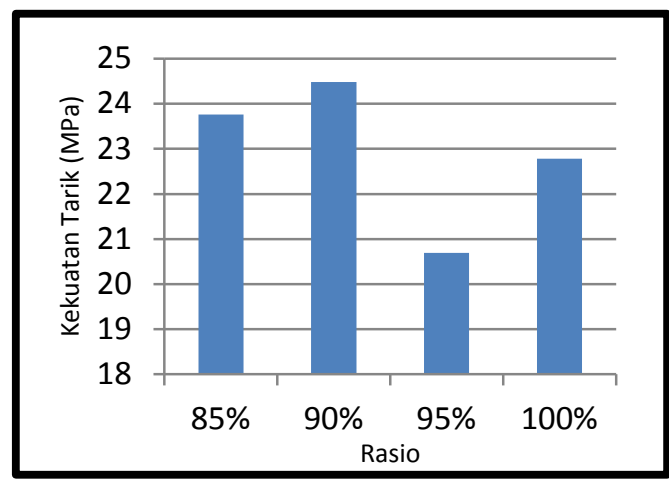

Gambar 2. Grafik Kekuatan Tarik Komposit untuk Penentuan Rasio Optimum Komposit

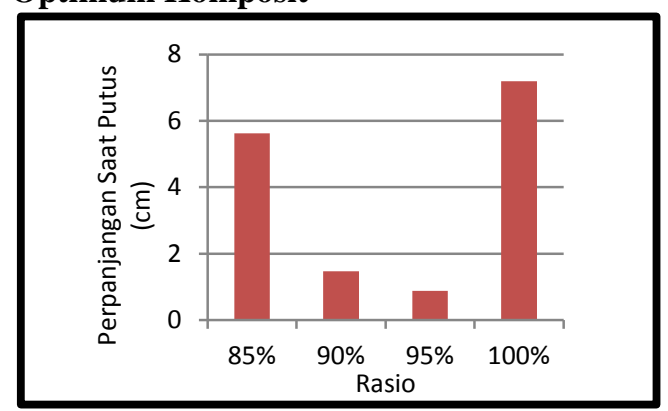

Gambar 3. Grafik Perpanjangan Saat Putus Komposit untuk Penentuan Rasio Optimum Komposit
Dari hasil percobaan untuk penentuan rasio optimum komposit diperoleh bahwa rasio optimum komposit adalah pada $85 \%$ dimana kekuatan tariknya adalah $23,765 \mathrm{MPa}$ dan pemanjangan saat putus $5,627 \mathrm{~cm}$. Rasio $90 \%$ memiliki kekuatan tarik tertinggi yaitu 24,481 $\mathrm{MPa}$ namun memiliki pemanjangan saat putus yang rendah yaitu $1,469 \mathrm{~cm}$. Sehingga hasil ini diperoleh bahwa rasio optimum komposit PP bekas berpengisi serbuk serabut kelapa adalah $85 \%$.

B. Perbedaan Kekuatan Bentur pada Komposit dengan pengolahan $\mathrm{NaOH} 1$ dan 2 hari

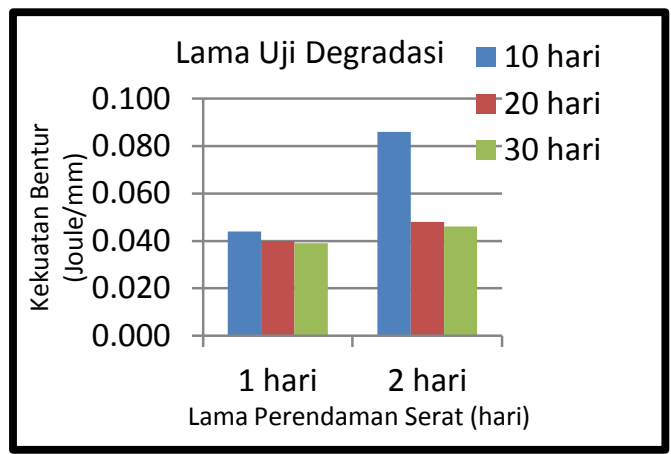

Gambar 4. Grafik Kekuatan Bentur Komposit pada uji Degradasi Komposit dengan pengolahan $\mathrm{NaOH} 1$ dan 2 hari

Dari hasil grafik yang diperoleh, dapat dilihat bahwa kekuatan bentur komposit lebih baik dengan perendaman 2 hari dibandingkan dengan 1 hari pada tiap uji degradasi, yaitu $0,086 \mathrm{~J} / \mathrm{mm}$ pada 10 hari, $0,048 \mathrm{~J} / \mathrm{mm}$ pada 20 hari dan $0,046 \mathrm{~J} / \mathrm{mm}$ pada 30 hari.

Hal ini disebabkan karena pada serabut kelapa terdapat lignin dan selulosa yang bersifat non polar. Adapun pengaruh dari perendaman $\mathrm{NaOH}$ terhadap serat adalah untuk melepaskan lignin yang terdapat pada serabut kelapa, sehingga kadar Lignin yang bersifat non polar di dalam serabut kelapa dikurangi yang menyebabkan tingkat kenonpolaran serabut kelapa berkurang [10].

Dari percobaan yang dilakukan diperoleh bahwa perendaman selama 2 hari menunjukkan keadaan yang optimum walau terjadi penurunan kekuatan bentur yang signifikan dari pada hari ke-20, namun kekuatan bentur pada perendaman selama 2 hari sedikit lebih baik dibandingkan perendaman selama 1 hari. 


\section{Perubahan Kekuatan Bentur pada uji Degradasi Komposit dengan pengolahan $\mathrm{NaOH} 1$ dan 2 hari}

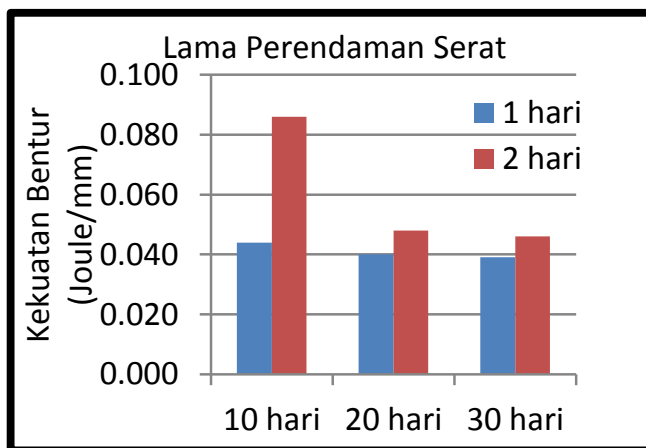

Gambar 5. Grafik Kekuatan Bentur Komposit pada uji Degradasi Komposit dengan pengolahan $\mathrm{NaOH} 1$ dan 2 hari

Dari hasil percobaan yang diperoleh, dapat dilihat bahwa kekuatan bentur komposit tidak begitu banyak mengalami perubahan pada perendaman $\mathrm{NaOH}$ selama 1 hari, sedangkan pada perendaman selama 2 hari terjadi penurunan kekuatan bentur dari 0,086 $\mathrm{J} / \mathrm{mm}$ pada 10 hari, $0,048 \mathrm{~J} / \mathrm{mm}$ pada 20 hari dan $0,046 \mathrm{~J} / \mathrm{mm}$ pada 30 hari.

Dari teori yang didapat, diketahui bahwa penurunan kekuatan bentur diakibatkan oleh komposit yang terpapar oleh sinar UV dan suhu. Penurunan sifat kekuatan bentur komposit disebabkan oleh gugus-gugus karbonil pada komposit menyerap sinar UV pada saat penjemuran dan penggantungan yang kemudian membentuk keadaan tereksitasi yang cukup berenergi untuk melakukan pembelahan/pemutusan ikatan. Selain itu, di udara juga terkandung banyak mikroorganisme yang didukung faktor lingkungan seperti suhu, uap air, sinar matahari, oksigen, dan kelembaban yang berasal dari pohon di dekatnya. Adapun plastik PP merupakan jenis termoplastik yang sensitif terhadap paparan radiasi dan panas matahari secara langsung, sehingga hal ini yang menyebabkan menurunnya kekuatan bentur pada komposit. [13]

\section{Kesimpulan}

Adapun kesimpulan yang didapat dari penelitian ini adalah sebagai berikut:

1. Kekuatan bentur mengalami penurunan selama pengujian degradasi, yaitu 0,086 $\mathrm{J} / \mathrm{mm}$ pada 10 hari, $0,048 \mathrm{~J} / \mathrm{mm}$ pada 20 hari dan $0,052 \mathrm{~J} / \mathrm{mm}$ pada 30 hari.

2. Waktu optimum untuk perendaman dengan $\mathrm{NaOH}$ adalah selama 2 hari yang berasal dari kekuatan bentur yang lebih baik daripada perendaman 1 hari.

3. Pengaruh larutan alkali pada serbuk serabut kelapa adalah mengurangi kadar lignin yang bersifat non polar sehingga tingkat kenonpolaran serbuk serabut kelapa berkurang.

\section{Daftar Pustaka}

[1] Diharjo, Kuncoro, Pengaruh Perlakuan Alkali terhadap Sifat Tarik Bahan Komposit Serat Rami-Polyester. Universitas Negeri Sebelas Maret, 2006.

[2] Delft University of Technology, Composite Applications using Coir Fibres in Sri Lanka. Netherlands, 2004.

[3] Joseph K., dkk, Effect of Ageing On The Physical And Mechanical Properties of Short Sisal Fibre Reinforced Polyethylene Composites. Composites Science Technology, Oxford, 1995.

[4] Luqman, Faruq, Coconut Coir as Natural Fibers For Polymer Composites. Perlis: University Malaysia Perlis, 2008.

[5] Mohanty, A. K, Coir-Polyester Composites: Effect On Fibre Surface Treatment On Mechanical Properties of Composite. India, 2000.

[6] Priyono, SKS, Komitmen Berbagai Pihak dalam Menanggulangi Illegal Logging. Jakarta : Konggres Kehutanan Indonesia III, 2001.

[7] Reynolds, Tom George, Accelerated Tests of Environmental Degradation in Composite Materials. Massachusetts Institute of Technology, 1998.

[8] Rohatgi, P. K, Alkali Treatment For Coir Fibres For Coir-Polyester Composites. India, 1983.

[9] Corning, Dow, Degradation of Polymers in Nature. Health Environment \& Regulatory Affairs (HERA), 1998.

[10] Halimatuddahliana, Pengenalan Teknologi Polimer. Departemen Teknik Kimia Fakultas Teknik. Medan : Universitas Sumatera Utara, 2006.

[11] Hariadi, Ihsan, Jurnal Fisika Bahan Komposit (1) dan (2). Milis Fisi Indonesia. www.Themailarchive.com, 2000.

[12] Ismail, H, Komposit Polimer Diperkuat Pengisi dan Gentian Pendek Semula Jadi. Malaysia: Universiti Sains Malaysia, 2004.

[13] Stevens, M. P. Polimer Chemistry. London: Oxford University Press, 1989.

[14] Anonim, Coir. http//www.wikipedia.org. Diakses 4 April 2011. 
[15] Anonim, Polypropilene. http// www.wikipedia.org. Diakses 4 April 2011.

[16] Titan PP Polymers, Catalog of Chemicals. Titan PP Polymers (M) Sdn. Bhd. Malaysia, 1999 